\title{
Legal Support for Participative Decision-Making as Part of 'Service' Model of Urban Governance in Russia
}

Svetlana E. Martynova, ${ }^{+*}$ Vladimir V. Tabolin, ${ }^{*}$ and Polina V. Sazonova ${ }^{\dagger}$

\section{Abstract}

The research deals with urban governance in Russia from the perspective of the participative approach to decision-making. The authors used quantitative (semi-structured 'face-to-face' interview) and qualitative (in-depth semi-structured interview) sociological surveys in five cities of Russia over the period from 2001 to 2017 regarding the public expectations towards the service activity of the urban governance authorities. The respondents were the citizens over 18-years-old who live in Tomsk, Seversk, and Strezhevoy in Tomsk Region. The authors have analysed the official documents and the information of the federal and municipal level over the period from 1997 to 2018. It was stated that the citizens' preferences had changed from paternalistic to 'service' ones, but in most cases, the legal framework was based on the directive principle of decision-making and did not comply with public demands. The technology of participative decision-making in the sphere of public services in Russia, in particular, in the cities, gradually develop. The content of such decisions increasingly reflects public expectations. Taking into account the results of the sociological surveys and the analysis of the regulatory support for the public service delivery, the authors have developed the recommendations on the improvement of the legal regulation based on the participative principle.

Keywords: Postindustrial Society; Service Public Governance; Participativity; Technology; Laws and Regulations; Urban Governance

\footnotetext{
${ }^{+}$Department of State and Municipal Management, Tomsk State University, 634050, 36 Lenin Ave., Tomsk, Russian Federation

${ }^{*}$ Corresponding Author, Email: status.sm@mail.ru

¥ Department of Public Law and Legal Support of Management, State University of Management, 109542, 99 Ryazan Ave., Moscow, Russian Federation
}

(C) 2019 Martynova et al. This is an Open Access article distributed under the terms of the Creative Commons Attribution License (http://creativecommons.org/licenses/by/2.0), which permits unrestricted use, distribution, and reproduction in any medium, provided the original work is properly cited. 


\section{Introduction}

The leading position of the actor in the new sociality has become an initial point in the scientific apprehension of social transformations, including the changes in the paradigm of governance (Sztompka, 2006; Touraine, 2007; Bidaishiyeva et al., 2018). Due to the fact that an independent and active actor needs no custody on the part of the government, the concept of governance was replaced by the 'service' one - a client-focused model (Djellal et al., 2013; Kruks-Wisner, 2011; Purcărea et al., 2013; Pyon et al., 2009; Sobaci \& Karkin, 2013).

Since 2005, the concepts and decrees of the government have emphasised the effective channels of the civil society's influence on the preparation and adoption of the executive authorities' decisions (Government of the Russian Federation, 2005; Government of the Russian Federation, 2014a; Ministry of Economic Development of the Russian Federation, 2018). The task of expansion of the citizens' participation in the formation of the governmental 'services' standards and the control over their execution is set (Government of the Russian Federation, 2009; President of the Russian Federation, 2012; State Duma, 2010). Therefore observed the growing level of the citizens' demands, the improvement of the quality of services and setting the service standards (Lall \& Lundberg, 2007; Silagadze, 2017; Abikenov et al., 2019). In addition, the following services have also been recognised:

- need for the public service to adjust to the rapidly changing requirements of the consumers (Coste \& Tudor, 2013);

- expectations of the citizens have been defined as basic at the development of the standard (Maslov, 2009);

- careful attitude to the public needs (Asmu'I \& Fitriati, 2014) and even to the individual ones is announced as the main aim of the state and municipal administration (Rodrigues et al., 2018).
However, the varied forms of legal services are classified as follows:

- Mass, socially significant services: economic development, environmental services, social services, protective, communal and recreational services (Desrieux et al., 2013; Khaidarov, 2008; Van et al., 2017);

- Individual and administrative services.

The participative mechanism of these various legal services is widely manifested as follows:

- consulting the locals;

- public disputes and hearings;

- sociological surveys;

- monitoring of the citizens' resorts (Gavrilova, 2012);

- Internet-voting, creation of blogs, websites, chats, forums and integration of the applications (Avzalova, 2015);

- crowdsourcing commissioned by the state and municipal authorities using online platforms (Liu, 2017).

Taking these background into consideration, the key objective of the research is to develop the recommendations on the improvement of the legal regulation based on the participative principle based on the public expectations connected with the 'service' activity of the municipal authorities (Kolesnikov et al., 2018).

An important particularity of the participative mechanism is public decision-making (Lerner \& Secondo, 2012; Atanelishvili \& Silagadze, 2018). The participative mechanisms in the scientific literature are considered applicable to the budgeting process, elaboration of the territorial development strategies (Mekhova, 2011; Silagadze, 2018) and the formation of the state and municipal staff (Rozanova, 2013). These algorithms and means of communication can act as a guide at the development of participative technology and applicable to the 'service' governance (Busetti \& Dente, 2016). The main aim of the legal regulation should be ensured at 
least normal, but more preferable - comfortable conditions of the urban community's living and activities (Tabolin, 2012). To accomplish the objectives, the following issues are taken into consideration:

- the model of "service" public government;

- analyse the object of research and methods that were carried out in the process of the sociological survey;

- analyse "service" expectations of the Russian citizens according to the results of the sociological research;

- study the normative documents that provide "service" activity of governance bodies;

- consider the client focus of legal support for the implementation of public services in the creation of the regulatory framework;

- develop the proposals on the development of the legal framework of participativity.

The next section reviews the relevant literature.

\section{Literature Review}

In recent decades, the development of public administration systems in developed countries is characterised by fundamental changes. The level of publicity of public administration systems directly depends on the exchange of information, both between different authorities of public administration and between government agencies, business and population. Public administration issues in the framework of administrative reform in Russia are studied in different research works (Barabashev \& Utkina, 2014; Tabolin, 2012; Ushakov et al., 2017 and the others).

Similarly, the research works of Silagadze (2017); Vialova L (2004); Karlina (2013); Volkova (2013) and the others are dedicated to the problems of improving the management system at different levels of government, including, taking into account the increasing role of factors of information technology. Despite the fact that the problems of development and formation of new models of public administration, in general, are reflected in sufficient detail in scientific, regulatory and statistical literature, one should note that the issues on increase of the public administration's publicity in Russia by increasing the involvement of the population, business and other public institutions in the process of decision-making, providing feedback mechanism from the population and business to the state, formation and acceleration of information flows between subjects of management decisionmaking due to more effective use of information technology factors, are paid not enough attention to (Arduini \& Zanfei, 2014).

The main problem of new public administration and, at the same time, a prerequisite for the appearance of scientific and practical interest for the category of "publicity" is the fact that governments ignore the role of citizens in the resolution of public disputes, therefore, according to T. Nabatchi, "they [governments] are unlikely to be able to determine the public value and prevent a value crisis" (Nabatchi, 2012: 701).

Nowadays, a trend of moving the emphases of public administration away from the state, its authorities and representatives, is evident. Instead, the population, or individual groups of the population, are considered as a subject of management due to their direct involvement in the process of development, adoption and implementation of decisions (Maslov, 2009). In this context, the object of management itself becomes, to some extent, the subject of management. The mechanisms of involvement are the principles of transparency, participativeness (involvement of civil society institutions, citizens themselves in the technology of management impact) and the creation of new institutions to represent the interests of individual groups and segments of the society and other technology (Kail \& Yepinina, 2013) The materials and methods are discussed in the following section.

\section{Materials and Methods}

As stated above, both quantitative and qualitative sociological surveys were deployed, 
coupled with the analysis of the laws and regulations. For the analysis, the authors used the results of the surveys of 2001-2017 conducted under the guidance of S.E. Martynova in five cities of Russia. The methods for the data collection were as follows: for the quantitative surveys - semi-structured 'face-to-face' interview was conducted, and for the qualitative surveys, we conducted in-depth semi-structured interviews. The total number of respondents in the quantitative surveys is 12945 . The respondents were the citizens over 18 -years-old who live in Tomsk, Seversk, and Strezhevoy in Tomsk Region. The samplings are quoted by sex and age based on the statistical data. The inaccuracy of the obtained data for each city at every wave of interviewing does not exceed $4 \%$ with the probability belief of 0.95 .

The analysis is based on the results of the following surveys:

- conducted in Tomsk and Seversk in 2001, 2002, 2004, 2005, 2011-2015;

- conducted in Strezhevoy in 2004, 2005, 2012-2015.

P.V. Sazonova conducted in-depth interviews in 2015-2017 among middle-class representatives, mostly businesspeople. The total number of respondents is seven. We also substantiate with the scientific data regarding the fact that the papers in the sphere of public service are more often based on the information collected particularly using the interview (Arduini and Zanfei, 2014).

The analysed corpus of the materials of the federal and municipal level includes the laws of the Russian Federation (RF), decrees of the RF President, orders of the RF government, staterun programmes, concepts, provisions, inventories, registers and the standards of the municipal services. Here, we focus mainly on the needs of the service recipient and the principles of the decision-making process.

\section{Results and Discussion}

The 'Service' Expectation of the Russian Citizens According to the Results of the Sociological Surveys
In the years 2001-2005, the 'service' expectations about public services of Russian citizens (in our case, Siberian cities inhabitants) were measured. The data obtained shows that their expectations were mainly focused on the solution of such acutest problems as low income and low quality of the municipal and housing services with their inadequately high cost.

These problems became the leaders in the answers of the citizens of the following cities (the years of conducting the research are indicated in brackets ):

- Seversk (2001, 2002, 2004);

- Strezhevoy (2005);

- Tomsk (2001, 2002, 2005).

The urban population in 2001-2005 expected from the local administrations the implementation of both paternalistic (ensuring income) and 'service' (ensuring the quality of public services) functions. In 2011, in the regional centre, one can note the change of the list of priority problems of the population in the direction of the prevalence of public services. . Apart from the main tasks, the deputies of the Duma should focus on the following:

- beautification $(20.2 \%$ of the total number of respondents);

- building new kindergartens (11.4\%);

- control over the work of housing and municipal services (9\%).

Let us considered the expectations connected with the activities of the municipal authorities, which is based on the data of the monitoring of satisfaction with the cities administrations' work in 2012-2015. Motives of the negative evaluation of the local administrations are revealed in the open question and presented in Table 1 (there is the percentage of the general number of respondents, without taking into account of the number of those who gave no evaluation).

Thus, in 2012-2015, one can judge the citizens' expectations which were mainly connected with the development of cities that would have visible results, and with improving the quality of public 
services. These expectations are the most demonstrative in the cities and the years where and when the negative assessments of the administrations' activities prevail the positive ones. These attributes are confirmed by the data of Tomsk in the years of 2012, 2013 and 2015 and Seversk in the years of 2013 and 2015. The analysis of the data proves the priority of the expectations connected in particular with the development of the cities and increase of the quality of the public services. The paternalistic mindsets remain prevailing; however, they take the first position only in the mono-industry city (Seversk, 2012-2015).

Results of the in-depth interview represent the middle class of the Russian cities: both capital (Moscow), and large peripheries (Tomsk and Novosibirsk) (Annex 1). Based on the surveys, we can conclude the following:

1. Respondents demonstrate the attitude of independency regarding ensuring their own well-being (Annex 1, A).

2. Even if by some or other reasons, the statebased financial support should be provided to citizens, the respondents do not get such help (Annex 1, B).

3. Public social services for children (education and healthcare service) are relevant to the respondents. The quality of these services even becomes a condition to keep on living and working in Russia. The main preferences of the respondents are connected with the individualisation of the social services, which encourages the middle-class representatives to choose private service suppliers (Annex 1, C).
4. The non-admittance is provoked by standardisation in the sphere of social services conducted without taking into account the needs of the consumers, together with the absence of the opportunity of individualising the services, presence of inconsistent bureaucratic documents not considering the needs of the service recipients (Annex 1, D).

The results of the sociological research allow to state that in the first decade of the 21st Century the paternalistic mindsets were strong, but in the second decade of the 21st century, the 'service' expectations began to prevail.

\section{Analysis of Laws and Regulations, Ensuring 'Service' Activity of the Administration}

The delivery of the services implies the interaction with the consumers at all the stages of the formation and rendering of the services. Let us now consider the regulatory framework from the perspective of the opportunity obtained by the consumer to impact the contents of the services.

The handling of solid municipal waste is included in the inventory of the municipal services paid by the consumer (State Duma, 2004). The regulation of the relations between the consumers and executors in the sphere of the services of the urban waste removal is implemented in accordance with the 'Rules for the Delivery of Services in the Sphere of Removal of Solid and Liquid Household Waste' (Government of the Russian Federation, 1997). These rules might be called client-focused: the cost of the household waste removal, terms of these services delivery, payment procedure and the form are stipulated by the agreement between the executor and consumer. 


\begin{tabular}{|c|c|c|c|}
\hline City & $\begin{array}{l}\text { Positive } \\
\text { Assessment }\end{array}$ & $\begin{array}{l}\text { Negative } \\
\text { Assessment }\end{array}$ & $\begin{array}{l}\text { Motives of Negative Assessment (the first three most } \\
\text { popular answers) }\end{array}$ \\
\hline \multicolumn{4}{|l|}{2012} \\
\hline Tomsk & $23 \%$ & $31.5 \%$ & $\begin{array}{l}9.5 \% \text { - lack of particular actions making the difference; } \\
6.4 \% \text { - rubbish and mud in the city; } 2.3 \% \text { - the poor } \\
\text { quality or lack of maintenance of the houses and } \\
\text { entrance halls. }\end{array}$ \\
\hline Seversk & $42.1 \%$ & $24.6 \%$ & $\begin{array}{l}12.1 \% \text { - lack of particular actions, positive changes in the } \\
\text { city's life; } 3.4 \% \text { - lack of jobs; } 1.8 \% \text { - employees of the } \\
\text { administration care only about themselves. }\end{array}$ \\
\hline $\begin{array}{l}\text { Strezhe } \\
\text { voy }\end{array}$ & $27.9 \%$ & $7.1 \%$ & $\begin{array}{l}4.2 \% \text { - lack of specific actions and results; } 0.9 \%-\text { no } \\
\text { beautification, but there can be seen mud and rubbish in } \\
\text { the city; } 0.4 \% \text { - lack of assistance on the part of the } \\
\text { administration's employees by the complains and } \\
\text { requests of the citizens. }\end{array}$ \\
\hline \multicolumn{4}{|l|}{2013} \\
\hline Tomsk & $26.5 \%$ & $39.1 \%$ & $\begin{array}{l}11.1 \% \text { - lack of certain actions, social and economic } \\
\text { development; } 9.2 \% \text { - no beautification, but there can be } \\
\text { seen mud and rubbish in the city; } 5 \% \text { - poor and not } \\
\text { cleared roadways. }\end{array}$ \\
\hline Seversk & $21.5 \%$ & $42.7 \%$ & $\begin{array}{l}21 \% \text { - lack of certain actions which lead to positive } \\
\text { changes; } 7 \% \text { - no beautification, no collection of garbage } \\
\text { and trash containers; } 4 \% \text { - lack of jobs. }\end{array}$ \\
\hline $\begin{array}{l}\text { Strezhe } \\
\text { voy }\end{array}$ & $54.6 \%$ & $5.4 \%$ & $\begin{array}{l}4.6 \% \text { - lack of certain actions which lead to positive } \\
\text { changes; } 2.8 \% \text { - no beautification; } 1.1 \% \text { - low } \\
\text { qualification and lack of doctors in the city hospital. }\end{array}$ \\
\hline \multicolumn{4}{|l|}{2014} \\
\hline Tomsk & $40 \%$ & $26.3 \%$ & $\begin{array}{l}7.6 \% \text { - no beautification, but there can be seen mud and } \\
\text { rubbish, in winter - snow and ice; } 5.8 \% \text { - lack of } \\
\text { particular actions making the changes; } 2.2 \% \text { - poor } \\
\text { roadways. }\end{array}$ \\
\hline Seversk & $36.2 \%$ & $16.1 \%$ & $\begin{array}{l}5 \% \text { - lack of specific actions which lead to the } \\
\text { development of the city; } 1.9 \% \text { - no beautification and } \\
\text { rubbish removal; } 1.3 \% \text { - lack of jobs. }\end{array}$ \\
\hline $\begin{array}{l}\text { Strezhe } \\
\text { voy }\end{array}$ & $41 \%$ & $24.6 \%$ & $\begin{array}{l}5.5 \% \text { - a permanent increase in prices; } 2.7 \% \text { - lack of } \\
\text { certain actions which lead to positive changes; } 1.2 \% \text { - } \\
\text { lack of doctors. }\end{array}$ \\
\hline \multicolumn{4}{|l|}{2015} \\
\hline Tomsk & $20.9 \%$ & $28.4 \%$ & $\begin{array}{l}7.5 \% \text { - lack of certain actions and visible results of work; } \\
5.6 \% \text { - no beautification (particularly, at the suburbs), } \\
\text { much rubbish and mud; } 4.7 \% \text { - very bad roadways. }\end{array}$ \\
\hline Seversk & $27.6 \%$ & $33.5 \%$ & $\begin{array}{l}13.3 \% \text { - lack of certain actions, positive changes, and } \\
\text { perspectives for the city; } 5 \% \text { - poor roadways; } 3.3 \% \text { - lack } \\
\text { of new jobs and enterprises. }\end{array}$ \\
\hline $\begin{array}{l}\text { Strezhe } \\
\text { voy }\end{array}$ & $32.2 \%$ & $19.2 \%$ & $\begin{array}{l}3.6 \% \text { - no beautification, playgrounds, pavements, } \\
\text { irregular rubbish removal; } 2.9 \% \text { - lack of assistance to the } \\
\text { population, certain actions, and positive changes; } 1.8 \%- \\
\text { high rates for the housing and municipal services. }\end{array}$ \\
\hline
\end{tabular}


Insignificant opportunities of taking into account the interests of the consumers are provided by the standards of Federal Law (State Duma, 1998; State Duma, 2017). Therefore, a standard agreement on services delivery of handling solid municipal wastes approved by the government of the Russian Federation can be supplemented with other provisions through the consent of the parties (Art. 247). The local authorities can set these provisions because according to the Law On Concerning the General Principles of the Local Administration Management in the Russian Federation, the collection and removal of household wastes belong to local issues (State Duma, 2003). It should be noted that on the official websites of the relevant municipalities (Administration of Seversk, 2018, Local government of Strezhevoy, 2018; Municipal Formation "City of Tomsk", 2018), the service of the rubbish removal is not mentioned (only the individual services as per by the applications of the citizens are presented). Consequently, the opportunity of introducing suggestions and assessments connected with the service is a priori absent.

The special attention should be paid to the education of children. The educational standards are elaborated and approved by the federal authorities (State Duma, 2012). The representatives of public organisations are only the members of the council who consider the suggested projects of the standards (Government of the Russian Federation, 2013a). Thus, the opportunities of the influence on their content by the consumers of the educational services are limited.

However, parents get a wider range of opportunities for influencing on many essential aspects of education. Notably, according to the Federal Law On Concerning, the Education in the Russian Federation, the opinion of the parents' councils is taken into account at setting the rules of enrollment and dismissal, schedule of lessons, form and regularity of the control over the education results. Also, parents can choose an education form, extracurricular and elective disciplines taking into accounts the opinion of their children (State Duma, 2012).
The state-run programmes of the RF on the educational development up to 2020 are aimed at the achievement of the educational results according to the changed demands of the population and the transition from the system of mass education, which is proper to the industrial society, to the individualised education of the post-industrial epoch:

- Federal Targeted Program on the Educational Development for the Period of 2016-2020 (Government of the Russian Federation, 2015);

- The concept of Development of the Additional Children's Education (Government of the Russian Federation, 2014b).

A systemic priority is the establishment of great opportunities for initiative and activity of the recipients of educational services, local communities through their involvement in the development of the education system and management of the educational process, as well as directly in educational activity (Government of the Russian Federation, 2013b).

The municipal practice still shows a declarative nature of interaction in the sphere of educational services (Vinichenko et al., 2016). For example, while the Municipal Social Council on the Development of the Basic and Additional Education of Children in Tomsk includes the appointed representatives of the administration, in the Duma of the City and Department of Education of the City's Administration, the representatives selected a number of chairpersons for the municipalities' administration and public members (Municipal Formation "City of Tomsk", 2017a).

The regulatory framework regarding mass public services does not comply with the 'service' concept of management as it is based not on the participative, but the directive principle of the decision-making. Such a situation provokes further negative consequences: dissatisfaction of the citizens with the activities of the municipalities, punishment of the Heads organisations and the municipalities for low assessment by the population of the public 
services' quality, who provided that during the services delivery, the suppliers should have been governed with the regulatory documents which do not reflect the requirements of the service recipients.

Regarding the roadway maintenance, the assessment standard by the population of the administrations' Heads and the leaders of the organisations which directly implements these activities, is adopted (Government of the Russian Federation, 2012). In the result, the population assesses the quality of the roadway maintenance according to one category of the parameters while other standards implement the roadway maintenance itself.

\section{Client Focus of Legal Support of the Public Services Implementation in the Regulatory Framework Creation}

The most critical breakthrough towards the client focus which implies the defining vote of the service consumer took place in the solution of beautification issues as a part of 'Formation of Comfortable Urban Environment' Project (Council at the President of the Russian Federation for Strategic Development and Priority Projects, 2016). The residents themselves choose the variant of beautification, and the administration invests into it (Ushakov et al., 2017).

In Tomsk, the mayor decided on implementing all the citizens' suggestions if not in 2017-2018, then in the following period. During the implementation of the works as part of the social control over the activity of the contractual companies, the residents of Tomsk could apply to the relevant department of the City Administration with their recommendations (the Municipal Formation "City of Tomsk", 2017b).

There are three stages of a 'service' algorithm: revealing the social need in the services, documentation of the consumers' expectations and the assessment of the satisfaction with the service. However, the stated technology, particularly, of the 'service' activities, is revealed regarding the single mass service.

In general, the regulatory framework does not allow a consumer to influence the content of the service he pays for. Throughout the process from the collection of proposals to the final adoption of the document - a "black box" method is applied. Namely, the choice of certain provisions is made by the authorities and remains hidden from citizens. It is even more probable if the citizens have no information to compare all the delivered suggestions and with the content of the standard, and they are not able to check the process and results of the preferential voting for some or other project. The used E-platforms increase the openness of the decision-making process.

\section{Conclusion}

The technology of participative decision-making in the sphere of public services in Russia, particularly in the cities, gradually develop. The content of such decisions increasingly reflects public expectations. The fullest embodiment of the participative approach is observed in the sphere of the creation of comfortable urban environment (beautification) (Akhmetshin et al., 2017; Sharafutdinov et al., 2018).

The suggestions on the development of the regulatory framework on the participativity are as follows:

1. At the municipal level, the laws and regulations which govern the conditions on the service delivery should stipulate the mindsets towards participativity, are laid in the federal documents. The same thing also relates to the local level. Besides, the inventories of the municipal services should include not only the individual services but also the mass socially significant ones, which delivery organising is legally documented as a responsibility of the local administrations.

2. Citizens should have access to the legislative initiative on all matters connected with public services. For the legislative initiative, there are no limitations on the kinds of the bodies and officials competent for solving the issues set in the projects of the municipal laws and regulations.

3. It is necessary to remove the bureaucratic obstacles for wider use of the legislative initiative of the citizens: 
- to document the procedure of this law implementation in the regulations of the municipality;

- to facilitate the procedure of the creation of the initiative group;

- to reduce the time of consideration by municipalities and officials of the project from three months to one;

- to use the E-voting instead of a collection of signatures.

4. The use of the E-methods for the citizens' identification in the official municipal databases will allow not only to facilitate the conduction of any surveys and gathering the population. The necessary openness of the decision can be ensured through the legal documentation of the relevant terms of the E-voting and the local administration's responsibility for the adequacy of the adopted documents to the public opinion.

\section{Acknowledgements}

This work was supported by the Russian Foundation for Basic Research under the grant No. 19-011-00720. The subject of the project is the development of the scientific foundations of legal urbanology as a new integrated sphere in the legal science of cities.

\section{References}

Abikenov, A., Idrysheva, S. K., Zharbolova, A. Z., Apakhayev, N., Buribayev, Y. A., Khamzina, Z. A. (2019). The problems of effectiveness and implementation of the international legal norms of the states of the Eurasian Economic Union (EAEU). Bulletin of the Georgian National Academy of Sciences, 13(1), 175-181.

Administration of Seversk. (2018). Register of Municipal Services. Retrieved from https://seversknet.ru/municipal_services/mun_ serv_zato/

Akhmetshin, E. M., Barmuta, K. A., Yakovenko, Z. M., Zadorozhnaya, L. I., Mironov, D. S., \& Klochko, E. N. (2017). Advantages of cluster approach in managing the economy of the Russian Federation. International Journal of Applied Business and Economic Research, 15(23), 355-364.
Arduini, D., \& Zanfei, A. (2014). An Overview of Scholarly Research on Public E-Services? A Meta-Analysis of the Literature.

Telecommunications Policy, 38(5), 476-495.

Asmu'i, A., \& Fitriati, R. (2014). Applying Interactive Planning on Leadership in the Organization: The Case of Transforming Public Transport Services in Banjarmasin. ProcediaSocial and Behavioral Sciences, 115, 283-295.

Atanelishvili, T., \& Silagadze, A. (2018).

Formation of economic views in the ancient era. Bulletin of the Georgian National Academy of Sciences, 2(1), 191-196.

Avzalova, E. I. (2015). Internet Participation as a New Form of Political Participation of Citizens. Scientific Notes of Kazan University. Series Humanities, 157(1), 187-193.

Bidaishiyeva, A., Nadirova, K.K., Kuldinova, S., Apakhayev, N., Khamzina, Z.A., Buribayev, Y.A. (2018). Improving quality of legal regulation for social rights of family and child within new social course in the Republic of Kazakhstan. Journal of Legal, Ethical and Regulatory Issues, 21(1), 1544-0044-21-1-165.

Busetti, S., \& Dente, B. (2016). Designing multiactor implementation: A mechanism-based approach. Public Policy and Administration, 33(1), 46-65.

Coste, A., \& Tudor, A.T. (2013). Service Performance - between Measurement and Information in the Public Sector. ProcediaSocial and Behavioral Sciences, 92, 215-219.

Desrieux, C., Chong, E., \& Saussier, S. (2013). Putting all One's Eggs in One Basket:

Relational Contracts and the Management of Local Public Services. Journal of Economic Behavior \& Organization, 89, 167-186.

Djellal, F., Gallouj, F., \& Miles, I. (2013). Two Decades of Research on Innovation in Services: Which Place for Public Services? Structural Change and Economic Dynamics, 27, 98-117.

Gavrilova, I.N. (2012). Civic Participation in Russia and the Netherlands: Problems and Prospects. Problem Analysis and PublicManagement Design, 5(25), 6-13. 
Government of the Russian Federation. (1997). Decree of February 10, 1997 No 155 "On approval of the Rules for the provision of services for the removal of liquid domestic waste". Retrieved on 03 April 2019 from, http://pravo.gov.ru/proxy/ips/?docbody=\&nd= 102045555

Government of the Russian Federation. (2005). Order of October 25, 2005 No 1789-r "The Concept of Administrative Reform in the Russian Federation in 2006-2010". Retrieved on 03 April 2019 from,

http://pravo.gov.ru/proxy/ips/?docbody=\&nd= 102100675

Government of the Russian Federation. (2009). Decree of June 15th, 2009 N 478 "On a unified system of information and reference support for citizens and organizations on issues of interaction with executive authorities and local self-government bodies using the information and telecommunications network Internet". Retrieved on 03 April 2019 from, http://pravo.gov.ru/proxy/ips/?docbody=\&nd= 102130296

Government of the Russian Federation. (2012). Resolution of December 17, 2012 No. 1317 "On Measures for the Implementation of Presidential Decree No. 607 of April 28, 2008, "On Evaluating the Efficiency of Local SelfGovernment Bodies in the Urban Districts and Municipal Areas "and Subparagraph" $i$ "of Point 2 of the Decree of the President of the Russian Federation May 7, 2012 № 601 "On the main directions of improving the system of public administration". Retrieved on 01 April 2019 from, https://www.garant.ru/products/ipo/prime/d oc/70186210/

Government of the Russian Federation. (2013a). Decree of September 5, 2013 N 661 "On approval of the Rules for the development, approval of federal state educational standards and amendments thereto". Retrieved on 03 April 2019 from, http://pravo.gov.ru/proxy/ips/?docbody=\&nd= 102167206\& $\mathrm{rdk}=4$
Government of the Russian Federation. (2013b). Order of May 15, 2013 N 792-r "Development of Education" for 2013-020 years". Retrieved on 02 April 2019 from, https://xn--80abucjiibhv9a.xn-p1ai/\%D0\%B4\%D0\%BE\%D0\%BA\%D1\%83\%D0\% BC\%D0\%B5\%D0\%BD\%D1\%82\%D1\%8B/3409

Government of the Russian Federation. (2014a). Order of January 30, 2014 N 93-r "The concept of openness of federal executive bodies". Retrieved on 05 April 2019 from, http://pravo.gov.ru/proxy/ips/?docbody=\&nd= 102171010

Government of the Russian Federation.

(2014b). Order of September 04, 2014 N 1726$r$ "The concept of development of additional education for children". Retrieved on 07 April 2019 from, http://static.government.ru/media/files/ipA1N W42XOA.pdf

Government of the Russian Federation. (2015). Decree of May 23, 2015 N 497 "On the Federal Target Program for the Development of Education for 2016-2020 years". Retrieved on 05 April 2019 from, http://pravo.gov.ru/proxy/ips/?docbody=\&nd= 102372590\&rdk $=4$

Kail, Ya.Ya., \& Yepinina, V.S. (2013). Foreign experience of participatory orientation of public administration. National Interests: Priorities and Security, 2, 42.Barabashev, A. G., \& Utkina, V. V. (2014). On the difference between analytics of public administration and public administration as a scientific direction. Public administration, 47, 19-38.

Karlina, A.A. (2013). City Development Management: Municipal Sustainability, Process Approach. Samara: SNC RAN.

Khaidarov, R. R. (2008). Municipal Services: Comparative Analysis. Vlast, 8, 48-52.

Kolesnikov, Yu. A., Pavlyuk, A. V., Radachinsky, Yu. N., \& Rodionova, N. D. (2018). Problems of Implementation of Public-private partnership in Russia. European Research Studies Journal, 21, 187-197. 
Kruks-Wisner, G. (2011). Seeking the Local State: Gender, Caste, and the Pursuit of Public Services in Post-Tsunami India. World Development, 39(7), 1143-1154.

Lall, S. V., \& Lundberg, M. (2007). What are Public Services Worth, and to Whom? NonParametric Estimation of Capitalization in Pune. Journal of Housing Economics, 17(1), 3464.

Lerner, J., \& Secondo, D. (2012). By the People, for the People: Participatory Budgeting from the Bottom up in North America. Journal of Public Deliberation, 8(2), Article 2. Retrieved on 05 April 2019 from, https://www.publicdeliberation.net/jpd/vol8/is s2/art2

Liu, H. K. (2017). Exploring Online Engagement in Public Policy Consultation: The Crowd or the Few? Australian Journal of Public Administration, 76(1), 33-47.

Local government of Strezhevoy. (2018). Standards of Information Disclosure in the Sphere of Disposal (Burial) of Solid Household Waste of LLC "TRANSSIB". Retrieved on 05 April 2019 from, http://admstrj.tomsk.ru/163naseleniyu/index.php?option=com_content\&vi ew=article\&id=3166:000transsib\&catid=224: standarty-raskrytiyainformatsii-organizatsiyami-kommunalnogokompleksa\&ltemid=526

Maslov, D. V. (2009). Model CAF to Improve the Quality of Public Management. Public Service, 6, 67-69.

Mekhova, A. A. (2011). Foresight as a Modern Technology of Social Participation. Social Policy and Sociology, 8, 120-127.

Ministry of Economic Development of the Russian Federation. (2018). Assistance in the Development of Civil Society Institutions.

Retrieved on 07 April 2019 from, http://economy.gov.ru/minec/activity/sections /admReform/publicsociety/

Municipal Formation "City of Tomsk" (2017a). Results of the Federal Priority Project

"Formation of a Comfortable Urban

Environment" on the Territory of the Municipal
Entity "City of Tomsk". Retrieved on 03 April 2019 from, http://www1.admin.tomsk.ru/pgs/7zr

Municipal Formation "City of Tomsk". (2017b). Regulations on the Municipal Public Council for the Development of General Education and Additional Education for Children in the City of Tomsk. Retrieved on 03 April 2019 from, http://www1.admin.tomsk.ru/pgs/x3

Municipal Formation "City of Tomsk". (2018). List of Municipal Services. Retrieved on 05 April 2019 from, http://admin.tomsk.ru/pgs/2mn

Nabatchi, T. (2012). Putting the "Public" Back in Public Values Research: Designing Participation to Identify and Respond to Values. Public Administration Review, 72(5), 699-708.

President of the Russian Federation. (2012). Decree of May 7, 2012 No 601 "On the Main Directions of Improving the System of Public Administration". Retrieved on 06 April 2019 from,

http://pravo.gov.ru/proxy/ips/?docbody=\&nd= 102156335.

Purcărea, V. L., Gheorghe, I. R., Petrescu, C. M. (2013). The Assessment of Perceived Service Quality of Public Health Care Services in Romania Using the SERVQUAL Scale. Procedia Economics and Finance, 6, 573-585.

Pyon, C. U., Lee, M. J., \& Park, S. C. (2009). Decision Support System for Service Quality Management Using Customer Knowledge in Public Service Organization. Expert Systems with Application, 36(4), 8227-8238.

Rodrigues, A.B., Groenwold, J.A., Dias, R.S., \& Benassi, S.F. (2018). Municipal basic sanitation planning: A methodology of support for local public management and a case. Periodico Tche Quimica, 15(29), 319-332.

Rozanova, N. N. (2013). Improving the Reputation of the Authorities: The Prospects for Introducing a Public Assessment of the Performance of Public Civil Servants. Quality Age, 3, 22-25.

Sharafutdinov, R. I., Gerasimov, V. O., Akhmetshin, E. M., Yumashev, A. V., Pavlyuk, A. V., \& Luzina, T. V. (2018). Inclusive growth index 
assessment in the regions of the Volga Federal District of the Russian Federation. In Proceedings of the 31st International Business Information Management Association Conference - Innovation Management and Education Excellence through Vision 2020, pp. 3890-3902.

Silagadze, A. (2017). History of Georgian economic thought: Relation between the center and the region. Bulletin of the Georgian National Academy of Sciences, 11(4), 138-144.

Silagadze, A. (2018). Some aspects of economic ideas in Shota Rustaveli's "the knight in the panther skin". Bulletin of the Georgian National Academy of Sciences, 12(1), 161-167.

Sobaci, M. Z., \& Karkin, N. (2013). The Use of Twitter by Mayors in Turkey: Tweets for Better Public Services? Government Information Quarterly, 30(4), 417-425.

State Duma. (1998). Federal Law of June 24, 1998 No 89-FZ "On Production and Consumption Wastes". Retrieved on 04 April 2019 from, http://pravo.gov.ru/proxy/ips/?docbody=\&nd= 102053807.

State Duma. (2003). Federal Law of October 6, 2003 No 131-FZ "On the General Principles of the Organization of Local Government in the Russian Federation". Retrieved on 29 March 2019 from, http://pravo.gov.ru/proxy/ips/?docbody=\&nd= 102083574.

State Duma. (2004). The Housing Code of the Russian Federation of December 29, 2004 No 188-FZ. Retrieved on 30 March 2019 from, http://pravo.gov.ru/proxy/ips/?docbody=\&nd= 102090645.

State Duma. (2010). Federal Law of July 27, 2010 N 210-FZ "On the Organization of the Provision of State and Municipal Services". Retrieved on 25 March 2019 from, http://pravo.gov.ru/proxy/ips/?docbody=\&nd= 102140498.

State Duma. (2012). Federal Law of December 29, 2012 N 273-FZ "On Education in the Russian Federation". Retrieved on 28 March
2019 from,

http://pravo.gov.ru/proxy/ips/?docbody=\&first Doc $=1 \&$ lastDoc=1\&nd=102162745.

State Duma. (2017). Federal Law of January 31, 2017 No 503-FZ "On Amending the Federal Law on Production and Consumption Wastes and Certain Legislative Acts of the Russian Federation". Retrieved on 31 March 2019 from, http://www.consultant.ru/document/cons_doc _LAW_286766/\#utm_campaign=hotdocs\&utm _ source=consultant\&utm_medium=email\&utm_ content=body.

Sztompka, P. (2006). New Perspectives on Trust. American Journal of Sociology, 112(3), 905-919.

Tabolin, V. V. (2012). Sociality of City Law. State Power and Local Self-Government, 8, 3-6.

Touraine, A. (2007). Sociology after Sociology. European Journal of Social Theory, 10(2), 184193.

Ushakov, D., Akhmetova, S. G., \& Nevskaya, L. V. (2017). Economic growth and environmental performance: Correlation issues and future priorities. International Journal of Ecological Economics and Statistics, 38(4), 164-172.

Van, H. T., Huu, A. T., \& Ushakov, D. (2017). Liberal reforms and economic growth: Current issues and interrelations. Journal of International Studies, 10(4), 109-118.

Vialova, L.M. (2004). The procedure for working with citizens. Moscow: MTsFER.

Vinichenko, M. V., Makushkin, S. A., Melnichuk, A. V., Frolova, E. V., \& Kurbakova, S. N. (2016). Student employment during college studies and after career start. International Review of Management and Marketing, 6(S5), 23-29.

Volkova, A.V. (2013). Mechanisms and methods for introducing the management of public values: Russian and foreign practices. Tambov: Gramota.

Annex 1. Extracts from the in-depth interviews conducted by P.V. Sazonova in 2015-2017 among middle class representatives

A 
"I do not seek for the support anywhere except in my own family" (Novosibirsk, 2017)

"Frankly speaking, I have never turned to any state funds of business support. We always rely only on our own powers and finance" (Tomsk, 2017)

\section{B}

"Maternity capital - yes, I have a certificate. If I used it, I would say something about it, but I have had no reasons to use it yet" (Tomsk, 2017)

\section{C}

"I have already found the school where I would be ready to send my junior son. I like an individual approach to the children there. To my mind, it is like the Western schools, where they practice a thematic approach to teaching various disciplines in the format of projects. It teaches to work in the team and show one's own personality" (Novosibirsk, 2017)

D

"I plan to send my child to a kindergarten. And, particularly, to a private one, because in the state kindergartens there is a more complicated attending schedule. We often have trips with our child, and we would always have troubles connected with it" (Moscow, 2015).

"The Ministry of Education has adopted a Decree that in case of 20-percent disease incidence the group should be quarantined. But the Ministry of Healthcare has no idea about it and provides the sick certificates only in case if the quarantine is made on a serious disease. What should the parents do in this case? As a result, we have to take the sick leave or stay with the child at home" (Novosibirsk, 2017) 